DOI 10.14746/ssp.2014.1.9

\title{
Irina MOSPANENKO
}

Państwowy Czarnomorski Uniwersytet im. Petra Mohyły, Ukraina

\section{Местное самоуправление во взглядах представителя немецкой политической мысли второй половины XIX - начала XX века Р. Гнейста}

\section{Постановка проблемы в общем виде}

азвитие Украины по пути построения действительно демокра-
тического, правового, социального государства возможно только через развитие института местного самоуправления, который является ключевым элементом организации публичной власти в гражданском обществе.

Через институт местного самоуправления граждане, во-первых, получают возможность реализовывать свои разнообразные интересы; во-вторых, институт местного самоуправления играет важную роль в обеспечении прав и свобод личности; в-третьих, институт местного самоуправления, выступает противовесом усилению авторитарных начал во властной вертикали, потому что является институтом политической социализации, школой демократического воспитания граждан.

Актуальность темы статьи, определяется, с одной стороны тем, что развитие института местного самоуправления в Украине зависит от того какая теория (концепция) местного самоуправления будет положена в основу его построения; а с другой невозможно без концептуального осмысления теорий местного самоуправления, разработанных представителями западноевропейской политической мысли второй половины XIX - начала XX века формировать свою, украинскую концепцию местного самоуправления. Поэтому исследование западноевропейской политической мысли второй половины XIX - начала XX века, когда основные концепции местного самоуправления были разработаны, является важным для современной политической науки и практики государственного строительства в Украине. 
Актуальность темы данной статьи усиливается также тем, что в Украине, на современном этапе её развития, продолжается процесс реформирования политической системы, идут поиски оптимального соотношения между центром и регионами. Многие из этих проблем в развитии местного самоуправления уже стояли на повестке дня в Западной Европе. Тем более актуальной представляется необходимость научного осмысления концепций местного самоуправления в западноевропейской политической мысли. Особенно интересной в этом плане является государственная концепция местного самоуправления в целом, и её политическое направление, которое было разработано представителем немецкой политической мысли XIX - начала XX века Рудольфом Гнейстом.

\section{Анализ последних исследований и публикаций}

Западноевропейская политическая мысль второй половины XIX - начала XX века посвященная теориям (концепциям) местного самоуправления рассматривается в работах многих европейских, российских и украинских ученых, начиная с момента их появления. Некоторые аспекты поставленной в статье проблемы изучаются такими зарубежными и отечественными учеными, как А. Верещагин, В. Григорьев, А. Евтушенко, Г. Еллинек, Н. Коркунов, Ю. Панейка, И. Редлих, А. Черкасов, В. Чихладзе и другие.

В статье использованы работы самого немецкого ученого Р. Гнейста: История государственных учреждений Англии и Правовое государство и административные суды Германии. А также работа Л. Штейна Учение об управлении и право управления с сравнением литературы и законодательств Франции, Англии и Германии: руководство.

Надо отметить, что если в советский период западноевропейские концепции местного самоуправления рассматривались главным образом под критическим углом зрения противоречий буржуазной теории и практики местного самоуправления, то после провозглашения Украиной независимости отношение к проблемам местного самоуправления кардинально меняется. Оно стало рассматриваться как важнейший механизм демократической самоорганизации граждан, как важнейшая предпосылка построения в Украине правового государства и формирования гражданского общества. 
Постановка задания. Целью данной статьи является изучение взглядов на проблемы формирования института местного самоуправления, его сущность, функции и место в системе государственного управления представителя немецкой политической мысли второй половины XIX века Р. Гнейста.

\section{Изложение основного материала исследования}

Во второй половине XIX века общественная теория с ее идеализацией природы человека и его возможностей, роли образования в достижении обществом своих высших целей и „явной недооценкой консерватизма простых людей”, определенной „иррациональности коллективных социальных сил постепенно уступала место так называемой государственной теории самоуправления" (Черкасов, 1998, c. 13).

Выдающиеся немецкие ученые второй половины XIX века Л. Штейн и Р. Гнейст, критически оценив общественную теорию местного самоуправления, разработали основные положения государственной теории самоуправления, согласно которой самоуправление - это одна из форм организации местного государственного управления. Все полномочия в области местного самоуправления предоставляются государством, а их источником и основой является государственная власть. По их мнению, „сила самоуправления не в отделении его от государства, а в служении интересам последнего" (Штейн, 1874, с. 32). Но, в отличии от центрального государственного управления, местное самоуправление осуществляется местными жителями, которые непосредственно заинтересованы в результатах этого управления, чего нельзя сказать о государственных чиновниках центрального государственного управления, которые независимы от местного населения, не контролируются им и не всегда проявляют инициативу и самостоятельность в разрешении местных проблем.

Возникновение государственной теории самоуправления было связано с изменившимися социально-политическими реалиями второй половины XIX - начала XX века. Во-первых, процессы урбанизации и индустриализации ощутимо снижали степень изолированности и самодостаточности отдельных территорий. Во-вторых, внедрение достижений научно-технического прогресса, концентрация промышленности в крупных городских центрах, широкое развитие торговли 
сделали локальные территориальные образования более зависимыми от общенационального политического курса и от ситуации в других сообществах. В-третьих, идея о том, что правительство тем лучше, чем меньше оно управляет, уступила место идее о „государстве всеобщего благосостояния", полномочия которого не ограничивались бы лишь защитными и регулирующими функциями. Местные органы власти все чаще стали обращаться к центральным властям с просьбами о помощи, а центр, оказывая поддержку местным органам, пристально следил за тем, чтобы разрабатываемые им программы осуществлялись на местах должным образом и поступающие в местные бюджеты по правительственным каналам средства расходовались на соответствующие нужды (Чихладзе).

Таким образом, государственная теория впервые обозначила политический аспект самоуправления, который был связан с поисками критерия отличия муниципальной власти от государственной.

Представители государственной теории местного самоуправления полагали, что источником полномочий муниципальных органов является государственная власть. Но среди сторонников этой концепции существовал спор относительного того, каким образом можно согласовать выполнение органами самоуправления задач государственного управления с их самостоятельностью. Разность решения этого вопроса послужила причиной для возникновения в рамках государственной теории двух направлений: „политического” (Гнейст) и „юридического” (Штейн).

По мнению Р. Гнейста, существуют два предмета ведения местного самоуправления - государственный и общинный. В первом случае самоуправление правительственное, то есть уполномоченное центральным правительством. Во втором случае самоуправление экономическое в его основе лежит „система общинных налогов, назначаемых и расходуемых по усмотрению самой общины” (Гнейст, 1885 , с. 760$)$.

На примере Англии Р. Гнейст критикует концепцию «свободной общины», отрицая ее до государственный характер и опровергает „хозяйственную” теорию, считая обеспечение местных хозяйственных нужд чуждым природе self-government. По его мысли правительственное самоуправление (self-government) как результат нормотворческой деятельности государства более эффективно, чем общинное, потому что функции хозяйственного обеспечения, исполняются органами самоуправления с большими трудностями. Ученый пишет: в „основе 
английского самоуправления лежит не община отдельной населенной местности, а административный округ” (Гнейст, 1885, с. 337).

Таким образом, самоуправление по Р. Гнейсту это государственное управление округов и общин. А государственное управление, деятельность особого рода, содержание которой состоит в выполнении законов и других актов органов государственной власти путем разных форм организующего влияния на общественные явления и процессы (Гнейст, 1896, с. 40).

Основное различие политического и юридического направления государственной теории было в том, что сторонники политического направления, во главе с Р. Гнейстом, видели критерий самостоятельности местного самоуправления в особенностях механизма замещения муниципальных должностей. По их мнению, осуществление функций управления должно было выполняться без вознаграждения (безвозмездно), как почетная обязанность, а не как должность, дающая средства к существованию. Например, замещения должности мирового судьи и безвозмездное отправление им своих обязанностей по мысли ученого является главным гарантом самостоятельности и инициативы местного управления. Это дает возможность органам самоуправления самостоятельно осуществлять свою деятельность и оставаться экономически независимыми от правительства (Гнейст, 1885 , с. 789). По сути, они „абсолютизировали такие черты самоуправления, как публичность деятельности и выборность органов местного самоуправления, т.е. видели специфику природы муниципальных органов власти в особенностях их формирования”. Недостатком его точки зрения было то, что „служебная деятельность для выбранных народом лиц становится второстепенной, так как средства для существования им предоставляет другая деятельность" (Євтушенко, 2010, с. 42).

Сторонники юридического направления видели критерий самостоятельности местного самоуправления в том, что органы самоуправления являются не органами правительства, а органами местного населения, на которое государство возлагает осуществление определённой части своих задач (Григорьев, 2015, с. 31). Местное самоуправление трактовалось Л. Штейном, как децентрализованная форма государственного управления на местах. Л. Штейн считал, что местное самоуправление - это территориальный коллектив, который имеет статус юридического лица и вступает в правовые отношения с государством, а потому органы местного самоуправления является 
элементом системы государственного управления с особыми юридическими полномочиями и правами. По его мнению, местное самоуправление соединит в себе две основные функции - государственного управления и обеспечение интересов местных территориальных общин (Штейн, 1874, с. 32). Недостаток этой теории был в том, что „такой дуализм лишь в теории мог быть эффективным, но на практике всевластие государства, попросту выхолащивало волю местных общин” (Свтушенко, 2010, с. 43).

По мнению Р. Гнейста, все государственные институции с их принудительным характером и далеко идущими целями противопоставляются интересам общества, которое является отдельным организмом. Государство вынуждено образовать организм, основой которого есть позитивное право, и который сможет подчинять себе интересы общества и обяжет людей выполнять государственные обязательства. Этим государственным организмом, по мнению Р. Гнейста, есть местное самоуправление (Панейко, 2002, с. 73), точнее местное государственное управление, основная задача которого заключаются в исполнении решений государства. По мнению И. Редриха, Рудольф Гнейст, считал, что самоуправление образует исключительно то гармоничное соединение государства и общества, которое с политической точки зрения называется обыкновенно равновесием властей, а с правовой - правовым государством (Редлих, 1908, с. 349).

Как писал сам Р. Гнейст формирование правового государства - это „взаимное проникновение государства и общества в отдельных членах и слоях, сохраняющее государственному строю своеобразную неподвижность и непроницаемость, но вместе с тем большое постоянство, большую жизненную силу и способность к развитию" (Гнейст, 1896, с. 25). Он подчеркивал, право-государственное состояние зависит от самоуправления общества, которое входит в правительственную власть как необходимый элемент.

Определение самоуправления Р. Гнейст основывает на взглядах, которые выплывали с его абстрактной государственно-общественной философии. В его трудах термин „местное самоуправление” (self-government) употреблялся в значении „управление на местах”, при котором территориальные исторические сложившиеся общины имели право самостоятельно, в рамках законов, решать местные дела. Община в своей деятельности освобождалась от вмешательства центральной государственной администрации и её чиновников на местах (Основные, 1996, с. 12-14). 
Под влиянием гегелевской диалектики и государственной философии Л. Штейна, Р. Гейст рассматривает государство и общество как противоборствующие единицы. Если Л. Штейн теоретически обосновывал конституционную монархию как наилучшую форму правления, то Р. Гнейст решал туже задачу с помощью конкретных историко-правовых исследований. И, как отмечает российский исследователь А. Верещагин, вполне естественно, что Р. Гнейст обратился к государственному устройству Англии, этому классическому образцу устойчивого конституционного государства (Верещагин, 2002, c. 23).

Р. Гнейст на примерах, взятых из практики управления местными делами Англии, показал, что такие обязанности, как охрана общественного порядка, введение и сбор государственных и местных налогов, заведование путями сообщения, общественного призрения, выполняются органами местного самоуправления по поручению государства, которое возлагает эти обязанности на общины, исходя из целесообразности и в силу близости к населению, полагая, что они справятся с ними лучше и оперативнее государственных. В тех местностях, где не существует органов местного самоуправления, делами, составляющими их обычную компетенцию, заведуют государственные органы (Григорьев, 2005, с. 26).

По мнению Р.Гнейста, английский государственный строй представлял собой не что иное, как самоуправление, осуществленное на всех этажах власти. Его особенное восхищение вызывал институт мировых судей, назначаемых королем из числа местных землевладельцев (gentry), обладавших определенным имущественным цензом. Должности свои они отправляли безвозмездно, как почетную обязанность. Это, по Р. Гнейсту, гарантировало их независимость от центральной бюрократии, поэтому и не развившейся в Англии до размеров континентальной, а также от частых смен правящих кабинетов - следовательно, обеспечивало устойчивость всего государственного здания (Гнейст, 1885, с. 85).

Будучи яростным критиком демократических тенденций, представительницей которых он считал Францию, Р. Гнейст видел признак самоуправления в единоличном отправлении почетных должностей, а не в принципах выборности и коллегиальности, на которых зиждилось французское самоуправление (Верещагин, 2002, с. 23).

Р. Гнейст пояснял, что почётные должности должны замещаться по назначению правительства (это исходило из государственного 
характера самоуправления), но эти должности должны быть неоплачиваемыми, что является гарантией независимости от центральной администрации, так как человек, который получает вознаграждение за должность, всегда будет пребывать в зависимом положении и от должности, и от руководства. Эта система должна была обеспечить закрепление местного самоуправления в руках тех, кто занимает руководящее положение в обществе, тем самым, способствуя достижению „гармонии государства и общества”. Но в своей симпатии к аристократии Р. Гнейст и его последователи упускали то, что в Англии все местное управление в полном объеме служило интересам крупных землевладельцев (Страхов, 1964, с. 29; Редлих, 1908, с. 41). С ростом демократических идей дальнейшее существование этой системы оказалось невозможным, и в конце XIX века Англия перешла к системе самоуправления, основанной на избирательных должностях.

Р. Гнейст выделяет два вида местного самоуправления: верхнее самоуправление (которым было местное самоуправление в XVII и XVIII веках) и хозяйственное самоуправление (как следствие победы общества над государством, которое, по мнение Р. Гнейста, было воплощено в английских коммунальных реформах XIX века).

Хозяйственное самоуправление не является, по мнению Р. Гнейста, настоящим, то есть верхним самоуправлением. Верхнее самоуправление по определению Р. Гнейста - это система администрирования при помощи почётных министров, которые происходили из состоятельного класса и платили высокие налоги. Данная администрация существовала в Англии в XVIII веке и контролировалась соседями только в вопросах легальности своей деятельности. Именно такую администрацию Р. Гнейст называет термином „местное самоуправление”. А в коммунальных объединениях, развивающихся в XIX веке, учёный не видел настоящего самоуправления. Такие объединения он называет локальным управлением хозяйственными делами (Панейко, 2002, с. 74).

Учёный предположил, что зависимое положение чиновника обуславливается главным образом тем, что служба является для него источником средств существования. Чиновник относится к исполнению возложенных на него функций как к работе, за которую он получает материальное вознаграждение. Следствием этого является то, что он действует не в соответствии со своими убеждениями, а так, как требует от него начальство. Поэтому необходимым условием 
самостоятельности самоуправления должно стать установление безвозмездных, почетных должностей. Чтобы чиновник, выполняющий функции управления был экономически независимым от правительства и самостоятельным в своей деятельности лицом. В тоже время, анализируя опыт английского местного самоуправления, Р. Гнейст согласился с тем, что когда органы самоуправления выполняют задачи государственного управления, то замещение муниципальных должностей должно совершаться по назначению правительства (Григорьев, 2005, с. 32).

Принимая как существенный элемент понятия самоуправления обязанность выполнения почётными чиновниками локальной государственной администрации, которые имели „чистый министерский характер” и все права и обязанности государственных чиновников, Р. Гнейст отбрасывает в самоуправлении правовую особенность и формально-организационную проблему. С юридической точки зрения он ставит общины наравне с институтом судей присяжных. Именно поэтому, утверждает Р. Гнейст, нужно ввести регистрацию граждан, которые могли бы занять почётные самоуправленческие посты в общинах и обязать их принимать эти посты.

Следует отметить, что взгляды Р. Гнейста на природу местного самоуправления неоднократно поддавались критике. Так, российский исследователь Н. Коркунов отмечал, что Р. Гнейст придаёт исключительное значение экономической зависимости должностного лица органа самоуправления, в то время, как занимая государственную должность, чиновник получает также и дополнительные личные выгоды (Коркунов, 1909, с. 125).

Вначале XX века теория Р. Гнейста получила дальнейшее развитие в трудах немецкого учёного Нейкопа, развивая его теорию, ученый считал, что самоуправление должно быть независимым от министерского управления и подчиняться только законам государства, а поэтому не должно получать инструкций по управлению местными делами от какой-либо высшей власти.

Германский правовед Георг Еллинек тоже внес существенные уточнения в государственную теорию самоуправления. Соглашаясь с тем, что вопрос о местном самоуправлении имеет не только правовую, но и политическую основу. Ученый подчеркивал, что централизованное государство обязательно связано с недемократическим правовым режимом, т. е. является „полицейским государством”. „Этому государству” - писал Г. Еллинек - „новейшая теория противопос- 
тавляет государство децентрализованное, в котором государственные дела более или менее самостоятельно решаются государственными органами или союзами с пространственно ограниченной компетенцией” (Еллинек, 1908, с. 371). Что касается общины то ученый утверждал, что она не только имеет собственные права, но и выполняет государственные функции, поскольку государство пользуется общиной для своих целей, вводит её в свою административную единицу, отсюда - община имеет собственную компетенцию и компетенцию, порученную её государством (Еллинек, 1908, с. 67-71).

Таким образом, государственная теория местного самоуправления Р. Гнейста позволяет выделить главные критерии эффективного функционирования органов местного самоуправления, в основе которых лежат общие принципы развития самоуправления, которые применимы в Украине: принцип многообразия организационных форм местного самоуправления; принцип самостоятельности в решении местных дел; принцип рациональности использования местных материальных ресурсов.

\section{Вывод}

На основе анализа теоретического наследия Р. Гнейста, можно сформулировать следующие выводы:

1. Смысл политической теории местного самоуправления Р. Гнейста заключался в том, что основу самоуправления составляет совокупность юридических гарантий, обеспечивающих самостоятельность самоуправляющимся единицам.

2. Р. Гнейст и его сторонники противопоставляли центральным государственным чиновникам людей, выбранных местным населением, то есть акцент делался на выборность в местном самоуправлении, которая в основном и обеспечивала самостоятельность этих органов.

3. Концепция местного самоуправления, разработанная немецким ученым Р. Гнейстом, оказала большое влияние на ход муниципальных преобразований в Европе, на взгляды украинских и российских учёных в области местного самоуправления. Опыт концептуального осмысления теоретического наследия Р. Гнейста может и должен быть востребован в современной Украине. Основные положения теории государственного местного самоу- 
правления могут быть положены в основу территориальной организации власти в Украине с учетом специфических особенностей украинского социума и трансформационных процессов в государстве.

\section{Библиография}

Верещагин А. Н. (2002), Земский вопрос в России (политико-правовые аспекты), Москва.

Гнейст Р. (1885), История государственных учреждений Англии, Москва.

Гнейст Р. (1896), Правовое государство и административные суды Германии, Санкт-Петербург.

Григорьев В. А. (2005), Эволючия местного самоуправления. Отечественная и зарубежная практика, Киев.

Еллинек Г. (1908), Общее учение о государстве, Санкт-Петербург.

Євтушенко О. Н. (2010), Державна влада і місиеве самоврядування в політичній системі суспільства, Миколаїв.

Коркунов Н. М. (1909), Русское государственное право, Санкт-Петербург.

Основные теории местного самоуправления: происхождение и развитие (1996), Москва.

Панейко Ю. (2002), Теоретичні основи самоврядування, Львів.

Редлих И. (1908), Английское местное самоуправление. Изложение внутреннего управления Англии в его историческом развитии и современном состоянии, Санкт-Петербург.

Страхов Н. Н. (1964), Государство и право феодальной Англии, Харьков.

Черкасов А. И. (1998), Сравнительное местное управление: теория и практика, Москва.

Чихладзе Л. Т., Историко-теоретические аспекты развития местного самоуправления и местного управления в государствах Европь, „Право и политика" 2005, № 9-12, 2006, № 1, http://www.yabloko.ru/municipal/ library (1.03.2014).

Штейн Л. (1874), Учение об управлении и право управления с сравнением литературы и законодательств Франции, Англии и Германии, Санкт-Петербург, 1874. 


\section{Samorząd lokalny w poglądach przedstawiciela niemieckiej myśli politycznej drugiej połowy XIX - początku XX wieku R. Gneista}

\section{Streszczenie}

Niniejszy artykuł stanowi analizę - ogólną - poglądów politycznych niemieckiej szkoły R. Gneista oraz szczegółową - koncepcji samorządu terytorialnego tegoż badacza. Autor zgłębił poglądy R. Gneista na temat roli i funkcji samorządu terytorialnego w systemie administracji państwowej. W publikacji poruszono także problem sprawowania władzy przez urzędników honorowych.

\section{Local government as seen by $R$. Gneist - a representative of German thinking from the second half of the $19^{\text {th }}$ and early $20^{\text {th }}$ century}

\section{Summary}

The paper presents a general analysis of the political views of the German school of R. Gneist and a detailed analysis of his concept of local government. The author examines R. Gneist's ideas of the role and function of local government in the system of state administration. The paper also addresses the issue of honorary officials holding posts. 